\title{
PARTY POLITICAL COURSE AND UKRAINIAN HISTORY IN THE USSR*
}

\author{
Yakov Lazarev \\ Ural Federal University, \\ Yekaterinburg, Russia
}

This article offers contextual analysis of unpublished editorials from one of the issues of Voprosy Istorii academic journal, published in 1955. The issue focuses on the problems of studying the history of Ukraine and was written by N. L. Rubinstein, an outstanding Soviet historian and historiographer. The historian discusses the problems related to the history of Ukraine between the fifteenth and nineteenth centuries, as well as the formulation of the academic heritage of pre-revolutionary historians and the "school" of M. S. Grushevsky. The need to overcome a dependence on the conceptual heritage of "Ukrainian bourgeois-nationalist historiography", which, according to the historian, practically leveled the achievements of Ukrainian scholars, is a red thread through the article. A kind of "familiar track effect" caused significant gaps in the study of Ukrainian $17^{\text {th }}$ - and $18^{\text {th }}$-century history, as well as the dominance of negative assessments in understanding the process of integration of Ukraine into the Russian state. For the first time in Soviet historical science, the unpublished editorial voiced the need to overcome the monopoly on the study of Ukrainian history held exclusively by institutions of the Ukrainian SSR. In this regard, Rubinstein paid special attention to the Institute of History of the USSR Academy of Sciences, which, in his view, had to be transformed into a key organisational centre for future research. All this suggests a potential divide in the academic study of Ukrainian history in the USSR and its conceptual rethinking, since Rubinstein was highlighting existing research issues. Via the case study of the unpublished Rubinstein editorial, the author demonstrates how the production of academic texts and regulation of research in the USSR were

* This work is financially supported by a grant of the president of the Russian Federation meant to support young Russian scholars; the topic of the research is The 'Cossack State' in Moscow; Mechanisms of Preservation and Reproduction of the Ukrainian National Narrative in Soviet Academic Works (1934-1956) (MK-73.2019.6). Agreement 075-15-2019-1134 as of 13.06.2019. The author would like to express warm gratitude to M. A. Kiselyov, PhD (History), senior researcher of the Institute of History and Archaeology, Ural Branch of the Russian Academy of Sciences and V. V. Tikhonov, Dr. Hab. (History), for assistance, valuable advice, and comments which helped the author in carrying out the research.

** Citation: Lazarev, Ya. (2020). Party Political Course and Ukrainian History in the USSR. In Quaestio Rossica. Vol. 8, № 5. P. 1769-1784. DOI 10.15826/qr.2020.5.557.

Цитирование: Lazarev Ya. Party Political Course and Ukrainian History in the USSR // Quaestio Rossica. Vol. 8. 2020. № 5. P. 1769-1784. DOI 10.15826/qr.2020.5.557.

(C) Lazarev Ya., 2020

Quaestio Rossica • Vol. 8 • 2020 • № 5, p. 1769-1784 
closely intertwined with administrative academic positions and personal connections of Moscow academics and Ukrainian historians (sometimes informally). Under these conditions, the directives of the party leadership at the centre and in the provinces fell into a certain dependence on the internal organsation of the academic community. Existing personal connections opened the way for a kind of academic lobbyism. This kind of lobbying paved the way for the entry of controversial ideas, interpretations, and conceptions that did not fit into the existing ideological framework in the difficult political conditions of the day.

Keywords: history of Ukraine, Academy of Sciences, N. L. Rubinstein, A. M. Pankratova, Voprosy Istorii.

Представлен анализ концептуального, но неизданного проекта редакционной статьи журнала «Вопросы истории» (1955). Она была посвящена проблемам изучения истории Украины и написана выдающимся советским историком Н. Л. Рубинштейном. Основное внимание ученый сосредоточил на проблемах истории Украины XV-XIX вв., а также на рецепции научного наследия дореволюционных историков и школы М. С. Грушевского. Утверждалась необходимость пересмотра идей «украинской буржуазнонационалистической историографии», которые практически нивелировали достижения украинских историков. Своеобразный «эффект колеи» обусловил существенные лакуны в изучении украинской истории XVII-XVIII вв., а также доминирование негативных оценок в понимании процесса интеграции Украины в состав Российского государства. Впервые в советской исторической науке озвучивалась мысль о необходимости преодоления монополии на изучение украинской истории институциями УССР. Особое внимание Рубинштейн уделял работе Института истории АН СССР, который следовало трансформировать в ключевой организационный центр научно-исследовательской деятельности. Все это создавало потенциальную развилку в научном изучении украинской истории в СССР и ее концептуальном переосмыслении. На примере сюжета с отказом в издании работы Н. Л. Рубинштейна в статье показывается, как производство научных текстов и регулирование научного процесса в СССР были тесно переплетены с научно-административными позициями и личными связями московских академических и украинских историков (подчас неформального характера), что открывало дорогу для своего рода «научного лоббизма». Это позволяло в непростых политических условиях обговаривать идеи, трактовки и концепции, не вписывавшиеся в существовавшие идеологические установки.

Ключевые слова: история Украины, Академия наук, Н. Л. Рубинштейн, А. М. Панкратова, «Вопросы истории».

To fully understand the development of Soviet historical studies, one must take into account the difficult question of the level of influence of contemporary political and ideological trends upon the writing 
of history in the USSR. Sometimes such influence was elevated to the absolute, especially in the context of the study of national historiographies of the former Soviet republics. For this reason, it is important to describe the often invisible role of Moscow academic historians, i. e. their scholarly views and personal ties, with respect to their choosing and promoting of the 'politically proper' course for the interpretation of national histories and their conceptualization within the framework of the all-Union historiographic narrative. In modern Ukrainian historiography, Ukrainian historians of that time are mostly described as victims of the "totalitarian Moloch", fighting against the persistent denationalization of their own history, while managing to preserve their national historiographic heritage under the most challenging circumstances (primarily, the socalled "school" of M. S. Grushevsky) [Ясь].

I consider the problem stated above through a case study of the history of an unpublished editorial in the academic journal "Voprosy istorii", which formulated some of the problems facing the study of the Ukrainian history and, more broadly, the academic work of Ukrainian historians [HИOP РГБ. Ф. 521. Оп. 1. К. 12. Д. 12. Л. 2-10]. Intellectual history scholar, B. E. Stepanov, points out that "the study of Soviet periodicals in the postwar period remains a rather marginal field, both for intra-disciplinary historiographic reflection and for the history of Soviet science" [Степанов, с. 227]. It is difficult to disagree with his assessment, given the scarce developments in this area to date [Сидорова, 2000].

I chose to showcase the academic journal Voprosy istorii due to the fact that it has long had the status of a leading organ for historical studies in the USSR, including the Union republics. This journal was the only all-Union periodical that informed the wider public about developments in historical studies in the USSR (including the Union republics) and abroad. The journal reported on the work of academic and educational institutions, dissertation defenses, and reviewed important historical works. The decisive period in the history of the journal is associated with the leadership of Academician A. M. Pankratova. This prominent organizer of the historical scholarship of her time, and ardent conductor of the party line on the historical front, served as the journal's editor-in-chief between 1953 and 1957.

A key element in the construction of the journal's editorial policy were the editorial articles opening each issue. In the language of the time, such an editorial was called a peredovaya, and later, peredovitsa. These articles were often anonymous, symbolically emphasizing the unified, collective opinion of the Editorial Board, which gained a symbolic capital that was higher than that of regular academic discussions. Little is known about the authorship and pre-publication editing of these articles. As such, it is a great success to find a draft or manuscript copy of such an editorial (or prospective editorial).

In the case of the draft editorial by N. L. Rubinstein, it was written during the transformation of the journal "Voprosy istorii" in 19521953. At the closing stages of Stalinism in 1952, "Voprosy istorii" was 
severely criticized for their unsatisfactory work, first in the "Bolshevik" magazine (No. 13), and then in the editorials of "Voprosy istorii" itself. The starting point for these attacks were critical remarks made at the 19th Congress of the VKP(b) - CPSU by G. M. Malenkov in his speech about the incorrect interpretation of the national histories of Kazakhstan and Azerbaijan. The 9th and the 12th issues of "Voprosy istorii" (1952) featured anonymous editorials that, in accordance with popular practice of "criticism and self-criticism", indicated a number of "ideological and theoretical shortcomings" to the editors, headed then by P. N. Tretyakov. These shortcomings were primarily associated with criticism aimed at the work of the Institute of History of the USSR Academy of Sciences, and the journal in question was its de facto press organ. Among the identified shortcomings, the critics highlighted the following: first, the organization of the discussion "On the historical significance of the annexation of non-Russian nations to Russia". Presumably, the concept of the "least evil" by M. V. Nechkina had been confusing historians of some national republics when assessing certain historical events, while also jeopardizing their fight against "bourgeois nationalism". Secondly, not enough was done to "highlight the invaluable assistance that the great Russian nation provided to all the nations of our country." The latter was explained by the remnants of the influence of the M. N. Pokrovsky historical school, as well as by the insufficient efforts of the Institute of History in "raising qualified specialists in the history of the Union republics". The editorial board was reminded that "the party press has repeatedly pointed out the shortcomings and mistakes of the journal "Voprosy istorii", so their activities were "by a special resolution of the Presidium Of the Academy of Sciences of the USSR on October 17, 1952, rightly evaluated as unsatisfactory" [За дальнейший подъем, с. 11-12]. Other comments criticized shortcomings in the study of the history of Soviet society (the descriptive nature of works, the lack of proper criticism of a number of studies), as well as the lack of criticism of the unwelcome theories of N. Ya. Marr in archaeology (pejoratively referred to as "marrism") [Против субъективистских ошибок; Покончить с проявлениями марризма]. Such devastating criticism should have been followed by serious organizational reforms. However, such reforms were implemented only after Joseph Stalin's death in the spring of 1953.

On 28 May 1953, the head of the Department of Science and Culture of the Central Committee of the CPSU, A. A. Rumyantsev, prepared a report on the journal, "Voprosy istorii", addressed to N. S. Khrushchev. It summed up the previously stated shortcomings, which did not allow the journal "to fulfill the role of the leading organ for the historical science", and to participate in "a resolute struggle against bourgeois-nationalist perversions". The author of the report stressed that the journal did not pay attention to the work of "central or local research institutions" and did not influence them in any way (one of the examples being the Institute of History of the USSR Academy of Sciences). Moreover, the journal's 
editorial board broke away from the "wider academic community", relied on a "narrow circle of authors", and did not provide adequate assistance to young researchers. As a result, Rumyantsev proposed to appoint A. M. Pankratova (a member of the "Voprosy istorii" editorial board) as the new Editor-in-Chief, and E. N. Burdzhalov as her Deputy [Академия наук в решениях Политбюро, с. 65-66].

An abridged version of Rumyantsev's proposals were included in the Resolution of the Secretariat of the Central Committee of the CPSU from 28 May 1953, "On measures to improve the journal "Voprosy istorii", which was classified as "top secret". The final version of the document omitted the most odious charges, such as manifestations of "liberalism" towards "marrism" "in the field of history", the "narrowness" of the circle of published authors, the wrongness of the "direction" of academic institutions, including the USSR Academy of Sciences Institute of History, and removed ideological slogans about turning the journal into the "leading organ of the Soviet historical studies." However, the final resolution did preserve Rumyantsev's key objection, that the journal "does not pay due attention to the study of the history of the nations of the USSR ${ }^{1}$, nor does it provide due assistance in this matter to historians of the Soviet republics" [Академия наук в решениях Политбюро, с. 63-64].Thus, the harsh criticism of the journal "Voprosy istorii", which unfolded at the end of Stalin's primacy, became the basis for re-organizational decisions, taken later, after the former leader's deathand the associated collapse of the "zhdanovschina" (1946-1953) in historical studies. As a result, the main and permanent objective that was formulated for the new editorial board, headed by A. M. Pankratova (1897-1957), was active participation of the journal in the study of the history of the constituent nations of the USSR, as well as it giving academic and methodological assistance to historians in the republics. Taking into account such objectives, the choice of A. M. Pankratova to head the journal looked absolutely logical. Pankratova had previously led the publication of a number of collective works on the history of the nations of the USSR ("History of the Kazakh SSR", 1943). She had also actively participated in discussions on the processes through which various Soviet nations entered into the Russian state, and acted as a leading expert on the mistakes made by historians of the Soviet republics ("History of Ukraine: a Short Course", 1940) [Тихонов 2016, с. 105, 192-193; Письма Панкратовой, с. 54-56, 59, 62-66; Єкельчик, с. 145-180; Сидорова, 2012; Інститут історії України, 2011, с. 587-588].To understand how Pankratova followed the above mentioned objectives, which had their roots in the late Stalinist era, our focus now turns to one important source: a draft editorial written by the Soviet historian Nikolai Leonidovich Rubinstein (1897-1963), dedicated

\footnotetext{
${ }^{1}$ The draft resolution included "history of the formation and the development of the Soviet Socialist Nations".

${ }^{2}$ Repressive policy against the creative class, the intelligentsia, is originally associated with the name of A. A. Zhdanov (1896-1948), who was fond of the practice coined as "criticism and self-criticism".
} 
to the problems in the study of Ukrainian history in the USSR. This historian is better known as a specialist in the historiography of Russia ${ }^{3}$, rather than Ukrainian history. An exception is in the portrayal offered within the comprehensive academic memoir by S. S. Dmitriev (1964), in which the author, who was a friend and colleague of Rubinstein, used many of the historian's personal papers. The Ukrainian researcher N. N. Yusova also adds much to our understanding of Rubinstein's academic interests. The academic life of N. L. Rubinstein was rather difficult. According to Rubinstein himself, and his biographer, S. S. Dmitriev, the historian became interested in the conceptual study of Russian history as early his gymnasium studies, before divining his calling as the study of the socioeconomic history of Russia in the 18th and the 19th centuries. [Рубинштейн, 1962; Заруба, с. 265]. However, in the context of Ukrainization of higher education in the Ukrainian SSR (teaching in Ukrainian, emphasis on the history of the Ukraine), Rubinstein had to adjust his initial plans, turning instead to the study of the history of Kievan Rus. Despite this reorientation, Rubinstein's letters to his family reveal that new Ukrainian history themes - the era of Bohdan Khmelnytsky and RussianUkrainian relations in the $17^{\text {th }}$ and the 18 thcenturies - greatly attracted the young researcher during his postgraduate studies at the Odessa Institute of Public Education (under the supervision ofM. E. Slabchenko) [Дмитриев, с. 434]. In the 1920s and 1930s, Rubinstein began to explore the field of historical sociology, engaging in discussions about creating a real Marxist concept for Ukrainian history, which should be freed from the legacy of "old nationalistic concepts" ${ }^{4}$. The analysis of Rubinstein's writings and documents from this period shows that the politicized discussions among various Ukrainian historians about formulating the "right course" for the history of Ukraine were an important issue for Rubinstein. As a result of these discussions, a number of Ukrainian researchers were subjected to political repression as "bourgeois nationalists" (arrest of M. I. Yavorsky; criticism and defeat of the "school" of M. S. Grushevsky) [НИОР РГБ. Ф. 521. Оп. 12. Д. 1. Л. 39-39 об.]. This stage in the development of Soviet Ukrainian studies coincided with Rubinstein's move from Odessa to Moscow. The historian's relocation to the capital coincided with a break with his academic supervisor, M. E. Slabchenko, for whom Rubinstein turned from being one of the most talented and promising students into "a socially alien element for the Soviet science." This conflict was evidently worsened by a heavy teaching load, tiring teaching in the Ukrainian language ${ }^{5}$ and various

${ }^{3}$ It is enough to refer to the contents of the first obituaries and the latest biographical publications. In addition, N. L. Rubinstein himself did not specifically mention the works he wrote or lectures on Ukrainian history [Рубинштейн, 1962].

4 The First all-Union conference of Marxist Historians (December 28, 1928 - January 4, 1929) may be considered the starting point.

5 "I work in the IPE. Ukrainian language spoils my mood. $<\ldots>$ I feel quite silly when a student addresses me in Russian during classes, and I - following the orders - answer him in Ukrainian." 
part-time jobs outside the University, which jeopardized the academic work of Rubinstein [Дмитриев, с. 437, 444; Заруба, с. 153-154, 228]. In Moscow, Rubinstein did not relinquish his historical and sociological studies and even expanded into teaching special courses and seminars on Ukrainian history and historiography at the Moscow Institute for Philosophy, Literature and History (MIFLI) ${ }^{6}$ (1936-1937), as well as at Moscow State University (1940-1941). The historian periodically gave additional, standalone lectures at the Historical and Philosophical Institute of the People's Commissariat for Education ${ }^{7}$ (1936), where he also conducted seminars that were interrupted in the early 1940s. In the 1930s, N. L. Rubinstein did, however, give up writing articles on the history and historiography of Ukraine. An explanation for this shift is preserved in one of the undated versions of the historian's brief autobiography (possibly drafted in the late 1930s). According to Rubinstein, his "broader academic work was hindered by my fundamental differences with employees who were in charge of academic work at that time" - namely, S. I. Piontkovsky and N. N. Vanag (both executed in 1937). The latter, according to Rubinstein, criticized Rubinstein's "minor research work" on the "national-class struggle in Ukraine in 1648-1654", as "inconsistent with the general party line" and barred it from publication [НИОР РГБ. Ф. 521. ОП. 1. К. 1. Д. 1. Л. 18 об.].Despite this set back, Rubinstein subsequently managed to take on an important role as a specialist in Ukrainian history. This was not even prevented by the persecution that the historian was subjected to as part of the campaign against cosmopolitanism in historical studies in the late 1940s [Тихонов, 2016, с. 89, 134-135, 162, 174, 201-202, 204$205,207]$. As a reviewer, he analyzed academic articles and monographs of Ukrainian historians that were being prepared for publication or had already been published [НИОР РГБ. Ф. 521. Оп. 1. К. 1. Д. 6, 13, 14; К. 24. Д. 7, 20; Рубинштейн, 1954 $]^{8}$. Close cooperation with the "Voprosy istorii" journal played an important part in securing Rubinstein's status as a non-Ukrainian expert on Ukrainian history.

Largely due to this acknowledged expert status, N. L. Rubinstein was commissioned to prepare an editorial on the study of Ukrainian history in the USSR. The historian worked on the project in the first half of 1955, after the celebration of the 300th anniversary of the reunification of Ukraine with Russia. We can only guess about his true motives for writing the piece. In an undated letter to the Deputy editor-in-chief of "Voprosy istorii", E. N. Burdzhalov", Rubinstein wrote that "upon agreement", he submitted "a draft of some of my ideas on the desirable content of the planned article

${ }^{6}$ Moscow Institute of Philosophy, Literature and History named after N. G. Chernyshevsky, later merged with Moscow State University in 1941.

${ }^{7}$ People's Commissariat of the Enlightenment.

${ }^{8}$ In this case, we are talking about the remarks and reviews of N. L. Rubinstein on published or prepared for publication or defense works of Ukrainian historians of the Soviet era (V. A. Golubitsky, K. G. Guslisty, etc.).

${ }^{9}$ Most likely, the letter refers to the first half of 1955. 
on the history of Ukraine, and a number of outlines for the specific subject", the typescript of which was attached to the letter. According to Rubinstein, his observations were "merely indicative" in nature. At the end of the letter, he expressed hope that his notes "will not be completely useless" during the preparation of the editorial [НИОР РГБ. Ф. 521. Оп. 1. К. 12. Д. 12. Л. 1].

Rubinstein's "notes" constitute a detailed analysis of the successes and, most importantly, the problems and shortcomings evident in the study of Ukrainian history. It is the latter that deserves our closest attention. The first important point made by Rubinstein was his emphasis of the low number of publications by Ukrainian historians, who at that time had neither completed work on an academic two-volume History of the Ukrainian SSR, nor had they published sufficient "serious academic monographs", preferring to publish "popular science publications and bulletins". Another shortcoming of the Ukrainian academic community was the irregularity in its issuing of various "Academic notes" - often the only source for recent academic studies in provincial centers. As a result, "certain periods and stages of Ukrainian history were researched inadequately." Rubinstein gave as an example the study of the formation of the "Ukrainian people-nation" in the $14^{\text {th }}-16^{\text {th }}$ centuries, which in the interpretation of the leading Moscow slavist, V. I. Picheta, was "not supported by serious research", and "the formulation of questions of economic and social development of this period ... did not go beyond the factual material accumulated by bourgeois historiography and <therefore $>$ required critical assessment, analysis and reinterpretation from the standpoint of Marxist methodology" [НИОР РГБ. Ф. 521. Оп. 1. К. 12. Д. 12. Л. 3-4]. Rubinstein's dissatisfaction with one of the leading Soviet slavists could have been caused by the differences between Picheta and Rubinstein in their perception of the above issue, following correspondence between them which discussed the problem of understanding the history of Russia and Ukraine in the $17^{\text {th }}$ and the $18^{\text {th }}$ centuries $^{10}$.

Rubinstein, in particular, pointed to significant gaps in the study of $17^{\text {th }}$ and $18^{\text {th }}$ century Ukrainian history. The key factor hindering the academic study of this period was, according to the historian, the "perversions" of Ukrainian bourgeois-nationalist historiography. Rubinstein made his case by studying the socio-economic and political aspects of Russian-Ukrainian relations:

"The development of serfdom relations in Ukraine has not been properly studied, as a result of which there are still claims that serfdom in Ukraine was imposed by Russian politics, following the unification of Ukraine with Russia.

Ukrainian bourgeois-nationalist historiography also introduced many 'perversions' into the interpretation of Russian-Ukrainian relations in the first quarter of the 18th century (e. g., I. Dzhidzhora's works). Likewise,

${ }^{10}$ In this case, we are talking about the review by V. I. Picheta of the article by N. L. Rubinstein titled "History of the USSR" (232 p.) in the "Great Soviet Encyclopedia" (1947). This review contained numerous comments about Ukrainian history of the $17^{\text {th }}$ and $18^{\text {th }}$ centuries. Picheta noted: "It was not the division (of Ukraine under the Andrusov Truce of 1667. - Ya. L.) that generated discontent with the Russian government, but its overall policy. Why hide it? After all, Moscow sought to destroy the autonomy of Ukraine" [HИOP РГБ. Ф. 521. Оп. 1. К. 28. Д. 18. Л. 9]. 
Soviet historians referred to this issue only in passing (e. g. V. Shutoy's book about the Great Northern War). The subsequent development of RussianUkrainian relations and the reunification of Ukrainian lands with Russia during the 18th century had not been studied at all" [НИОР РГБ. Ф. 521. Оп. 1. К. 12. Д. 12. Л. 5-6].

In his critical notes for the "Voprosy istorii" editorial, N. L. Rubinstein also attacked the concept of the "least evil", in which the process of Ukrainian integration was viewed in a negative way. Behind his fiery rhetoric, a wellbalanced analysis of accepted ideas and the criticism of their sources is clearly visible. Assessing the degree and quality of the study of serfdom in Ukraine, the historian repeated the criticism expressed by the famous prerevolutionary historian V. A. Myakotin, who later emigrated from Russia.

The central thread of his prospective editorial was the conviction that it was necessary to overcome the dependence upon the conceptual heritage of "Ukrainian bourgeois-nationalist historiography", which practically leveled the achievements of Ukrainian historians (for example, in the study of the history of the 19th century $)^{11}$. As N. L. Rubinstein believed, in "researching the questions of historiography" "there is still a lack of any serious attempts at critique and academic rebuttal of Grushevsky's nationalist school of history, whose theories continue to be widely popular in bourgeois historical literature abroad." Moreover, the "Soviet historians of Ukraine" not only withdrew from proper research of these issues, but also mixed up the legacy of outstanding historians of the Ukrainian peasantry, such as A. M. Lazarevsky and V. M. Barvinsky, with the same school [НИОР РГБ. Ф. 521. Оп. 1. К. 12. Д. 12. Л. 8-9].

In conclusion, the historian gave recommendations on "the development of academic historical work in Ukraine", consisting of six points aimed at transforming the Institute of History of the Academy of Sciences of the Ukrainian SSR "into a true organizational center for academic research", focusing on the need to improve its professional level, create a coordinating body, and regularly publish journals. Rubinstein also stressed the need to "establish a close connection with researchers from other republics". The last (sixth) point of Rubinstein's proposals deserves special attention. Here, the historian gave a harsh evaluation of the Institute of History of the USSR and their research work: "problems of the history of Ukraine, as well as the history of other peoples of the USSR have not yet taken their proper place among the research themes" [НИОР РГБ. Ф. 521. Оп. 1. К. 12. Д. 12. Л. 9-10].

Part of the problems raised by N. L. Rubinstein, such as strengthening the position of the Institute of History of the Ukrainian AS, reinterpretation of the pre-revolutionary heritage (the school of M. S. Grushevsky), and wider academic journals publishing, had been actively discussed by the Ukrainian historians from the mid-1940s onwards (discussions that, at times, were quite heated) [Інститут історії України, 2011, кн. 1, с. 581]. At the same time,

${ }^{11}$ In this aspect, N. L. Rubinstein pointed out the works of B. L. Pogrebinsky, O. D. Bagaley, I. A. Gurzhiya, K. G. Guslistyi, and F. A. Yastrebov. 
cooperation with Moscow academic historians was beginning to increase. For the first time, Rubinstein voiced the need to overcome the monopoly on the study of Ukrainian history held by academic organizations of the Ukrainian SSR, which should be seen as anentirely academic effort to close the gaps that existed in the study of Ukrainian history, and to overcome existing academic "provinciality". The problems voiced by Rubinstein were very much in tune with the comments that led to the change of the editorial board of "Voprosy istorii" in May 1953. This created a very interesting fork in the academic study of Ukrainian history in the USSR and its conceptual reinterpretation for the future, since Rubinstein pointed out real research problems that were essential for the study of history.

However, Rubinstein's draft editorial never saw the light of day. Instead, in the $7^{\text {th }}$ issue of "Voprosy istorii", published in 1955, another anonymous editorial article appeared instead: "For the profound study of the history of the Ukrainian people” [За глубокое изучение]. The article noted the success of Ukrainian historians and local academic institutions, whose research "was fruitfully influenced by the works of B. Grekov, V. Picheta, M. Tikhomirov, S. Yushkov, and other Russian Soviet scholars". An important focus of the editorial was on the celebration of the $300^{\text {th }}$ anniversary of the reunification of Ukraine with Russia and the academic publications prepared for it, which demonstrated that "Ukrainian Soviet historians have undeniable achievements in covering and popularizing the history of the Ukrainian people." At the same time, the sharpness of Rubinstein's criticism was noticeably smoothed out. The published version habitually stated that it was necessary to study the history of Ukrainian lands from various aspects, starting from the $14^{\text {th }}$ century, with special emphasis on "the relations of the Ukrainian people with the Russian, Belorussian and Moldavian peoples". Then the anonymous author(s) went on to call for active participation "in the research of some fundamental problems raised by Soviet historiography" on the history of Kievan Rus and the economy of Ukraine "in the era of imperialism". In the same style, using stereotypical slogans, the anonymous author(s) called for the continuation and deepening of criticism of "bourgeois-nationalist historiography" and "the fight against reproduction of the Grushevsky school concepts", in order to develop a critical understanding of the pre-revolutionary heritage.

The author(s) of the editorial did not, however, ignore shortcomings in the study of Ukrainian history, referring to the Institute of History of the Ukrainian AS, where supposedly "the need for monographic publications on major problems of the history of Ukraine" was seriously overlooked. In addition, it was noted that "some employees of academic institutions in Ukraine do not produce academic outcomes for longer periods of time", and therefore such employees should be "replaced by the historians who are capable of creative academic activity". This argument was reinforced by the statement that "creative discussions on the most important problems of history are rarely held in Ukraine", "academic sessions and conferences are usually convened on the occasion of certain anniversaries and often have a ceremonial character" [За глубокое изучение, с. 4, 5, 8, 10]. 
Thus, the very specific, practical comments provided by N. L. Rubinstein were replaced with vague recommendations that simply focused on the relevance of studying the history of Soviet society. The editorial board chose to completely ignore the historian's thoughts about the role of the Institute of History of the USSR Academy of Sciences and other non-Ukrainian research centers in the study of Ukrainian history. It might be assumed that the final version of the "Ukrainian" editorial forced Rubinstein to reconsider his criticisms of the field, forcing him to choose carefully which ones he could publicly voice in the future. As an example, let us refer to Rubinstein's lengthy letter to the Editor-in-Chief of "Voprosy istorii", A. M. Pankratova, dated 20 June $1956^{12}$, where the historian discussed the problems of the development of Soviet historical studies that should have been brought to the attention of the Communist Party leadership ${ }^{13}$. Rubinstein devoted only a few lines to the problem of studying Ukrainian history per se, noting the great influence ("the monopoly") of the "Ukrainian counterrevolutionary emigration (Doroshenko and others)" on the interpretation of the "liberation war of the Ukrainian people" (1648-1654) and the apologetics of Hetman В. M. Khmelnitsky [АРАН. Ф. 697. Оп. 3. Д. 465. Л. 6].

As far as we can judge from the available documents, the published editorial did not have the effect that it might have had in the original Rubinstein version. Heads of some departments of the Institute of History of the Ukrainian AS often recirculated the published editorial using ideological clichés, noting that the existing thematic omissions would have been eliminated in the course of the 5-year plan (I. A. Gurzhiy ${ }^{14}$ ), or with the help of strengthening of personnel (F. E. Los' ${ }^{15}$ ), as well as by improving professional skills (such as learning foreign languages), purchasing academic literature in "capitalist countries", and foreign academic trips to the countries with people's democratic regimes (M. A. Rubach $\left.{ }^{16}\right)$. In isolated cases, there were notes of criticism for the academic work carried out at the Institute, but they mainly concerned the history of Ukraine during the period of capitalism and socialist development (about dogmatism and excessive scholastics in some unnamed works). Afterwards, the Academic Council of the Institute of History decided to inform the editorial board of the journal "Voprosy istorii" about the results of this meeting [У лещатах тоталітаризму, ч. 2, с. 192-201].

${ }^{12}$ In the upper-left corner of the letter there was a black pencil note: "The letter is printed. Ask if she is acquainted with its contents? A. M."

${ }^{13}$ The matter in question was the upcoming Plenum on ideology and the development of Social Sciences.

${ }^{14}$ I. A. Gurzhiy (1915-1971), head of the Department of Feudal History, and from 1958, Deputy Director of the Institute of History of the Ukrainian SSR Academy of Sciences, researcher of the history of Ukraine of the $18^{\text {th }}-19^{\text {th }}$ centuries.

${ }^{15}$ F. E. Los' (1908-1980), head of the Department of the History of Capitalism (Institute of History of the Ukrainian AS), researcher of Ukrainian history(late $19^{\text {th }}-$ early $20^{\text {th }}$ centuries).

${ }^{16}$ M. A. Rubach (1899-1980), head of the Department of Archaeography (Institute of History of the Ukrainian AS), researcher of agricultural relations between 1917-1920. 
The history of the rejection ofL.N. Rubinstein's editorial and the subsequent underplaying of criticism in the journal might need an explanation as to the "inner kitchen" of academic knowledge production in the USSR. As I see it, an important role here could have been played by the existing personal contacts between the Moscow academic circles and the Ukrainian historians that had been established back in the pre-war period [Ясь, с. 81-82, 104]. In addition to purely academic interests, these connections could have worked to adjust the political course of researchers and academic institutions, and to smooth out the sharper criticism. For example, this was true for the connections of A. M. Pankratova herself, through whom the Director of the Institute of History of the Ukrainian AS, A. K. Kasimenko ${ }^{17}$, tried to enlist support ("we ask for your sympathy, support and assistance") in "approving the blueprint" for the "Short Course in the History of Ukraine" in November 1947 [АРАН. Ф. 697. Оп. 3. Д. 323. Л. 1]. As subsequent events have shown, such hope was justified. For Pankratova, Kasimenko was an important figure within the academic administration, through whom she could implement the party ideals of the enlightenment in the right direction. In 1951, and not by chance, Pankratova supported Kasimenko's candidacy as a corresponding member of the Academy of Sciences of the Ukrainian SSR, citing the latter's highest level academic, pedagogical, editorial and administrative abilities over the last 20 years, which had been manifest both in the international arena and in the domestic academic field (Kasimenko developed a new periodization for Ukrainian history, and published a two-volume work on the history of the Ukrainian SSR) [AРАН. Ф. 697. Оп. 2. Д. 48. Л. 3-4]. Interestingly, Pankratova herself received controversial information about the difficult relationships in the research department led by Kasimenko, when his subordinates requested not just an intercession, but also for researchers to have an opportunity to use "Voprosy istorii" as a public platform for answering an unfair opponent ${ }^{18}$.. At the same time, the criticisms of N. L. Rubinstein indirectly, and in places directly, hit the reputation of the current leaders of historical science in the Ukrainian SSR, as well as the memory of former scholars (e. g., N. N. Petrovsky ${ }^{19}$ ). As such, the editorial was deemed inappropriate in its original version, which contained harsh criticism of the work of Ukrainian researchers and academic institutions. This was emphasized by the tone of the editorial that was ultimately published in the journal; the final version actually reinforced personal praise for Kasimenko and Petrovsky.

It should be added that the rest of the academic community in Moscow was sympathetic to the work of their Ukrainian colleagues. This can be

\footnotetext{
${ }^{17}$ As the first among the "first phalanges of Ukrainian historians who were taking the first steps towards establishing the deepest and the closest ties with the historians of Moscow".

${ }^{18}$ The unfolding of the conflict between the two leading Ukrainian historians - E. S. Kompan and D. I. Myshko - researchers at the Institute of History of the Ukrainian AS - is noteworthy. As far as one can tell, this conflict went beyond the limits of merely academic discussion [APAH. Ф. 697. Оп. 3. Д. 337. Л. 1, 3-5 (Письма Е. С. Компан к А. М. Панкратовой от 1 и 3 марта 1955 г.)].

${ }^{19}$ The candidacy of N. N. Petrovsky as a full member of the Academy of Sciences of the Ukrainian SSR was also supported by A. M. Pankratova in 1951, who noted his outstanding contribution to exposing the "bourgeois-nationalist anti-scientific views" (for example, the "school” of M. S. Grushevsky) [АРАН. Ф. 697. Оп. 2. Д. 48. Л. 1-2].
} 
seen, for example, in the content of reviews for Ukrainian publications, as well as in reviews for works and dissertations that were being prepared for publication [Зимин, Мочалов, Новосельский; АРАН. Ф. 1714. Оп. 1. Д. 83. Л. 27; Д. 85. Л. 10-18; Д. 86. Л. 48-54]. Moscow historians did not mention serious theoretical and methodological problems in the works of their Ukrainian colleagues, focusing solely on the value of the archival research, on historiographical study of the topic, and on the relevance of the conclusions made. In this regard, particularly noteworthy is a 1954 review of the first volume of the "History of the Ukrainian SSR", published in "Pravda", one of the leading socio-political newspapers in the USSR. The authors of the review (M. N. Tikhomirov, V. K. Yatsunsky, E. D. Chermensky, and S. S. Dmitriev) gave a generally positive assessment of the publication, despite some shortcomings.. Most importantly, Moscow academic historians united in a public defense of their Ukrainian colleagues from the criticism of P. Vershigora, a prominent figure in the partisan movement in Ukraine. The "politically erroneous and grossly tactless attack" of the latter, which denigrated this collective study, contained accusations regarding a lack of "creativity among the masses" and "patriotism" [Тихомиров, Яцунский, Черменский, Дмитриев].

This situation was almost a complete copy of a September 1948 controversy, when a group of Moscow academic historians, led by A. M. Pankratova (M. N. Tikhomirov, B. D. Grekov, S. V. Bakhrushin, and S. V. Yushkov), were focused on assessing the draft of the reviewed "Short Course of the History of Ukraine", which appeared as a result of harsh criticism from the Communist Party administration of the USSR (Propaganda Department of the CC CP(b)U). Local party officials claimed that the authors of the previous 1940 version of the "History" "borrowed key provisions, distorting the course of the historical process in favor of nationalism, from the bourgeois-nationalist historians such as Grushevsky, Antonovich, and others," and separated Ukrainian history from the history of other peoples of the USSR. However, Moscow historians had not identified significant errors in the presented draft, except for the insufficiently clear "class" identification of some historical figures (B. M. Khmelnitsky, I. S. Mazepa, among others), which was pointed out by Pankratova herself [Сидорова, 2012; Інститут історії України, 2011, с. 587-588].

In my opinion, the draft of N. L. Rubinstein's article that was sounding in unison with "zhdanovism" in historical research, and the criticismof "Voprosy istorii" from the central party authorities, proved to be doubly inappropriate; from the point of view of the changed political conditions, and because the attitude of Russian academic historians to their Ukrainian colleagues had not changed since the post-war years. In this regard, an attempt by Rubinstein, a historian who neither had his own "school", nor Academy of Sciences affiliation, to stage a small academic coup, had no chance of practical implementation.

The story of an unpublished Rubinstein's editorial for "Voprosy istorii" demonstrates that the production of academic texts and the overall regulation of academic research in the USSR were closely intertwined with the administrative academic positions and personal connections of Moscow- 
based scholars and Ukrainian historians (sometimes of an informal nature). It was this factor that allowed the academic community to preserve and maintain a relatively autonomous sphere of academic knowledge, where this dynamic was supported by various combinations of disputes, personal ambitions and controversies ${ }^{20}$. At the same time, personal connections opened the way for a kind of academic lobbying. Such lobbying allowed researchers to push controversial ideas, interpretations, or concepts that did not fit into existing ideological framework, but nevertheless gained "class" legitimacy in spite of difficult political conditions. The latter mostly concerns Ukrainian history of the 17th and the 18th centuries as understood by M. S. Grushevsky, who created in his works a negative image of the Russian state and government, and viewed critically the processes of integration of Ukrainian lands that, according to him, were damaging the development of the Ukrainian nation and its statehood. Despite the repeatedly declared policy of fighting "bourgeois nationalism" and the "school" of Grushevsky, such an approach was relatively easy to integrate into the all-Union narrative, becoming an important tool in exposing the "predatory plans" and "colonial policy" of "Russian tsarism". Notwithstanding the conditions of partial rehabilitation of the pre-revolutionary ("Imperial") narrative and the rise of the concept of "reunification" of Ukraine with Russia, this approach has undergone but minor changes.

\section{Список литературы}

Академия наук в решениях Политбюро ЦК РКП(б) - ВКП(б) - КПСС. 1922-1991 / отв. сост. В. Ю. Афиани, В. Д. Есаков. М. : РОССПЭН, 2010. Т. 2. 1952-1958. 1279 с. АРАН. Ф. 697. Оп. 2. Д. 48; Оп. 3. Д. 323, 337, 465; Ф. 1714. Оп. 1. Д. 83.

Дмитриев С. С. К истории советской исторической науки : Историк Н. Л. Рубинштейн (1897-1963) // Уч. зап. Горьк. гос. ун-та. 1964. Сер.: Историко-филологическая. Вып. 72. С. 415-478.

Єкельчик C. Імперія пам'яті. Російсько-українські стосунки в радянській історичній уяві. Київ : Критика, 2008. 303 с.

За глубокое изучение истории украинского народа // Вопр. ист. 1955. № 7. С. 3-10.

За дальнейший подъем исторической науки в СССР // Вопр. ист. 1952. № 9. C. $3-16$.

Заруба В. М. Михайло Слабченко в епістолярній та мемуарній спадщині (18821952). Дніпропетровськ : Юрид. акад. М-ва внутр. справ ; Ліра ЛТД, 2004. 352 с.

Зимин А. А., Мочалов В. Д., Новосельский А. А. Ценный труд по истории Украинской ССР // Вопр. ист. 1954. № 6. С. 128-132.

Інститут історії України НАН України : Документи і матеріали. 1936-1991 : у 2 кн. Київ : Інститут історії України НАН України, 2011. Кн. 1. 1936-1947. 630 с.

НИОР РГБ. Ф. 521. Оп. 1. К. 1. Д. 1; К. 12. Д. 12; К. 23. Д. 6, 13, 14; К. 24. Д. 7 , 20; К. 28. Д. 18.

Письма Анны Михайловны Панкратовой // Вопр. ист. 1988. № 11. С. 54-79.

Покончить с проявлениями марризма в археологии // Вопр. ист. 1952. № 12. C. $11-17$.

Против субъективистских ошибок в изучении истории советского общества // Вопр. ист. 1952. № 12. С. 3-10.

Рубинштейн Н. Л. Две научные работы по истории Освободительной войны украинского народа 1648-1654 годов // Вопр. ист. 1954. № 11. С. 133-139.

${ }^{20}$ This fact may be proved by referring to discussions of the history of the Central Asian republics of the USSR [Тихонов, 2017]. 
Рубинштейн Н. Л. О путях исторического исследования // История СССР. 1962. № 6. C. 8-114.

Сидорова Л. А. «Вопросы истории» академика А. М. Панкратовой // Историк и время : 20-50-е годы XX века. : А. М. Панкратова. М. : Изд-во РУДН : Мосгорархив, 2000. C. $76-84$.

Сидорова Л. А. «Краткий курс истории Украины» в контексте советской исторической науки конца 1940-х гг. // Былые годы. 2012. № 2 (24). С. 48-53.

Степанов Б. Е. Советская историческая периодика в 1950-1960-е годы: рамки и пределы модернизации // Сад ученых наслаждений : сб. тр. ИГИТИ к юбилею проф. И. М. Савельевой / отв. ред. Е. А. Вишленкова, А. Н. Дмитриева, Н. В. Самутина. М. : Изд. дом ВШЭ, 2017. С. 227-250.

Тихомиров М., Яиунский В., Черменский Е., Дмитриев С. Научный труд по истории Украины // Правда. 1954. № 108 (13 041). С. 2-3.

Тихонов В. В. Идеологические кампании «позднего сталинизма» и советская историческая наука (середина 1940-х - 1953 г.). М. ; СПб. : Нестор-История, 2016. 424 с.

Тихонов $B$. В. Российский государственный архив новейшей истории: документы Отдела науки и культуры ЦК КПСС (март 1953 г. - сентябрь 1955 г.) о контроле над «национальными историями» народов СССР // Вестн. архивиста. 2017. № 4. C. 135-146. DOI 10.28995/2073-0101-2017-4-135-146.

У лещатах тоталітаризму: Перше двадцятиріччя Інституту історії України НАН України (1936-1956рр.) : збірник документів і матеріалів : у 2 ч. Київ : Інститут історії України НАН України, 1996. Ч. 1. 146 с. Ч. 2. 247 с.

Ясь О. «На чолі республіканської науки...». Інститут історії України (1936-1986) : Нариси з інституціональної та інтелектуальної історії (до 80-річчя установи). Київ : НАН України : Ін-т історії України, 2016. 542 с.

\section{References}

Afiani, V. Yu, Esakov, V. D. (Eds.) (2010). Akademiya nauk $v$ resheniyakh Politbyuro TsK RKP $(b)-V K P(b)-K P S S$. 1922-1991 [Academy of Sciences in the Decisions of the Politburo of the Central Committee of the RCP(b) - VCP(b) - CPSU]. Moscow, ROSSPEN. Vol. 2. 1952-1958. 1279 p.

ARAN [Archive of the Russian Academy of Sciences, Moscow]. Stock 697. List 2. Dos. 48; List 3. Dos. 323, 337, 465; Stock 1714. List 1. Dos. 83.

Dmitriev, S. S. (1964). K istorii sovetskoi istoricheskoi nauki. Istorik N. L. Rubinshtein (1897-1963) [On the History of Soviet Historical Science. Historian N. L. Rubinstein (1897-1963)]. In Uchenye zapiski Gor'kovskogo gosudarstvennogo universiteta. Seriya: Istoriko-filologicheskaya. Iss. 72, pp. 415-478.

Ekel'chik, S. (2008). Imperiya pam'yati. Rosiis 'ko-ukraïns'ki stosunki v radyans'kii istorichnii uyavi [The Empire of Memory. Russian-Ukrainian Relations in the Soviet Historical Imagination]. Kiïv, Kritika. 303 p.

Institut istoriï Ukraïni NAN Ukraïni. Dokumenti i materiali. 1936-1991 u 2 kn. [Institute of History of Ukraine, National Academy of Sciences of Ukraine. Documents and Materials. 1936-1991. 2 Books]. (2011). Kiïv, Institut istoriï Ukraïni NAN Ukraïni. Book 1. 1936-1947.630 p.

NIOR RGB [Research Department of Manuscripts of the Russian State Library]. Stock 521. List 1. Carton 1. Dos. 1; Carton 12. Dos. 12; Carton 23. Dos. 6, 13, 14; Carton 24. Dos. 7, 20; Carton 28. Dos. 18.

Pis'ma Anny Mikhailovny Pankratovoi [Letters from Anna Mikhailovna Pankratova]. (1988). In Voprosy istorii. No. 11, pp. 54-79.

Pokonchit' $\mathrm{s}$ proyavleniyami marrizma $\mathrm{v}$ arkheologii [To End the Marrism in Archaeology] (1952). In Voprosy istorii. No. 12, pp. 11-17.

Protiv sub"ektivistskikh oshibok v izuchenii istorii sovetskogo obshchestva [Against Subjectivist Errors in the Study of the History of Soviet Society] (1952). In Voprosy istorii. No. 12, pp. 3-10.

Rubinshtein, N. L. (1954). Dve nauchnye raboty po istorii Osvoboditel'noi voiny ukrainskogo naroda 1648-1654 godov [Two Scholarly Works on the History of the War 
of Independence of the Ukrainian People in 1648-1654.]. In Voprosy istorii. No. 11, pp. 133-139.

Rubinshtein, N. L. (1962). O putyakh istoricheskogo issledovaniya [On Ways of Historical Research]. In Istoriya SSSR. No. 6, pp. 8-114.

Sidorova, L. A. (2000). "Voprosy istorii" akademika A. M. Pankratovoi ["Voprosy istorii" by Academician A. M. Pankratova]. In Istorik i vremya. 20-50-e gody XX veka. A. M. Pankratova. Moscow, Izdatel'stvo Rossiiskogo universiteta druzhby narodov, Mosgorarkhiv, pp. 76-84.

Sidorova, L. A. (2012). "Kratkii kurs istorii Ukrainy" v kontekste sovetskoi istoricheskoi nauki kontsa 1940-kh gg. ["A Short Course in the History of Ukraine" in the Context of Soviet Historical Science of the Late 1940s.]. In Bylye gody. No. 2 (24), pp. 48-53.

Stepanov, B. E. (2017). Sovetskaya istoricheskaya periodika v 1950-1960-e gody: ramki i predely modernizatsii [Soviet Historical Periodicals in the 1950s and 1960s: Scope and Limits of Modernisation]. In Vishlenkova, E. A., Dmitrieva, A. N., Samutina, N. V. (Eds.). Sad uchenykh naslazhdenii. Sbornik trudov Instituta gumanitarnykh istorikoteoreticheskikh issledovanii $k$ yubileyu professora I. M. Savel'evoi. Moscow, Izdatel'skii dom Vysshei shkoly ekonomiki, pp. 227-250.

Tikhomirov, M., Yatsunskii, V., Chermenskii, E., Dmitriev, S. (1954). Nauchnyi trud po istorii Ukrainy [Scholarly Work on the History of Ukraine]. In Pravda. No. 108 (13 041), pp. 2-3.

Tikhonov, V. V. (2016). Ideologicheskie kampanii "pozdnego stalinizma" i sovetskaya istoricheskaya nauka (seredina 1940-kh - 1953 g.) [The Ideological Campaigns of "Late Stalinism" and Soviet Historical Science]. Moscow, St Petersburg, Nestor-Istoriya. 424 p.

Tikhonov, V. V. (2017). Rossiiskii gosudarstvennyi arkhiv noveishei istorii: dokumenty Otdela nauki i kul'tury TsK KPSS (mart 1953 g. - sentyabr' 1955 g.) o kontrole nad "natsional'nymi istoriyami" narodov SSSR [Russian State Archive of Contemporary History: Documents of the Department of Science and Culture of the CPSU Central Committee on Control over "National Histories" of the Peoples of the USSR]. In Vestnik arkhivista. No. 4, pp. 135-146. DOI 10.28995/2073-0101-2017-4-135-146.

U leshchatakh totalitarizmu: Pershe dvadtsyatirichchya Institutu istoriï Ukraïni NAN Ukraïni (1936-1956 pp.). Zbirnik dokumentiv i materialiv u 2 ch. [In the Grip of Totalitarianism: The First $20^{\text {th }}$ Anniversary of the Institute of History of Ukraine of the National Academy of Sciences of Ukraine (1936-1956). Collection of Documents and Materials. 2 Parts]. (1996). Kiïv, Institut istoriï Ukraïni NAN Ukraïni. Part 1. 146 p. Part 2. $247 \mathrm{p}$.

Yas', O. (2016). "Na choli respublikans'koï nauki...”. Institut istoriï Ukraïni (19361986). Narisi z institutsional'noï ta intelektual'noï istorï (do 80-richchya ustanovi) ["At the Head of the Republican Science". Institute of History of Ukraine (1936-1986). Essays on Institutional and Intellectual History (To the $80^{\text {th }}$ Anniversary of the Institution)]. Kiïv, NAN Ukraïni, In-t istoriï Ukraïni. 542 p.

Za dal'neishii pod"em istoricheskoi nauki v SSSR [For the Further Rise of Historical Science in the USSR]. (1952). In Voprosy istorii. No. 9, pp. 3-16.

Za glubokoe izuchenie istorii ukrainskogo naroda [For Deep Study of the History of the Ukrainian People]. (1955). In Voprosy istorii. No. 7, pp. 3-10.

Zaruba, V. M. (2004). Mikhailo Slabchenko v epistolyarnii ta memuarnii spadshchini (1882-1952) [Mykhailo Slabchenko in the Epistolary and Memoir Heritage (1882-1952)]. Dnipropetrovs'k, Yuridichna akademiya Ministerstva vnutrishnikh sprav, Lira LTD. 352 p.

Zimin, A. A., Mochalov, V. D., Novosel'skii, A. A. (1954). Tsennyi trud po istorii Ukrainskoi SSR [Valuable Work on the History of the Ukrainian SSR]. In Voprosy istorii. No. 6, pp. 128-132.

The article was submitted on 20.07.2020 Translated by Anna Dergacheva 